\title{
Alteration Mapping in Central Urumieh-Dokhtar Magmatic Assemblage of Iran Using ASTER and OLI Data
}

\author{
Farshad Khodadadi*, Ramin Arfania \\ Department of Geology, Isfahan (Khorasgan) Branch, Islamic Azad University, Isfahan, Iran \\ Email: ${ }^{\star} 1$ khodadadi.farshad@gmail.com, rarfania@gmail.com
}

How to cite this paper: Khodadadi, F. and Arfania, R. (2017) Alteration Mapping in Central Urumieh-Dokhtar Magmatic Assemblage of Iran Using ASTER and OLI Data. Open Journal of Geology, 7, 1215-1226. https://doi.org/10.4236/ojg.2017.78081

Received: July 26, 2017

Accepted: August 21, 2017

Published: August 24, 2017

Copyright (c) 2017 by authors and Scientific Research Publishing Inc. This work is licensed under the Creative Commons Attribution International License (CC BY 4.0).

http://creativecommons.org/licenses/by/4.0/

\section{(c) (i) Open Access}

\begin{abstract}
The study area is located on the Urumieh-Dokhtar Magmatic Assemblage of Iran, in the west of Ardestan between the East longitude $52^{\circ} 1^{\prime}$ to $52^{\circ} 18^{\prime}$ and the North latitude $33^{\circ} 17^{\prime}$ to $33^{\circ} 27^{\prime}$. Remote sensing techniques are suitable for studying the alterations occurring in the igneous terranes. The alteration zones are well illustrated by implementation of the principal component analysis and the Crosta methods and Spectral Feature Fitting on ASTER data. In order to identify the lineaments, both Landsat- 8 satellite imagery and GDEM-ASTER data are used in spatial processing. Using directional filtering and automatic extraction of lineaments, a tectonic lineaments map is prepared. Then alteration maps, tectonic lineaments map and 1:100,000 geology map are used to identify areas with high potential of $\mathrm{Cu}$ mineralization.
\end{abstract}

\section{Keywords}

Principal Component Analysis, Crosta Method, Spectral Feature Fitting, Alteration, Lineament

\section{Introduction}

The study area is located in Ardestan region. This region, due to the presence of a large part of the Urumieh-Dokhtar volcano belt (Iran copper belt and gold metallogeny zone) as well as the Sanandaj-Sirjan zone (iron, gold, lead and zinc metallogeny zone of Iran), has a lot metallic and non-metallic mines. Due to the lack of systematic discovery and compliance with global standards, the province has high potential for unknown metal deposits even at ground level [1]. It uses ASTER-OLI satellite data and spectral methods for detecting alterations in this area for the first time. Due to the fact that the Urumieh-Dokhtar belt is a metal- 
logenic belt, study on alterations can lead to the exploration of new metal deposits.

The best guideline for detecting the copper mineralization is high density of fractures inside or around the intrusions [2]. Faults and fractures can affect mineralization by leading magma and hydrothermal fluids to shallower levels, and accumulate or concentrate metal elements [3]. Lineaments play an important role in the initial exploration of geological structures for the identification of minerals [4]. Therefore, areas with good mineral potential are associated with high density of faults and fractures. The study and processing of satellite data in identifying complications such as rock type, contacts, linear and circular structures, alteration and iron oxide zones can be used directly for the identification of mineral deposits [5]. One of the advantages of remote sensing technique is to identify a wide range with high precision and low costs [6]. Therefore, remote sensing and satellite image processing techniques play an important role in the exploration of mineral deposits. In this study, we identify the alteration zones with high potential for $\mathrm{Cu}$ mineralization using remotely sensed image processing methods.

Porphyry copper deposits typically occur in conjunction with hydrothermal alteration zones. In fact, a quartz nucleus is surrounded with potassium minerals, such as Orthoclase with multiple zones including clay and other hydroxyl group minerals with spectral absorption properties detected in the short-wave infrared spectrum of the electromagnetic spectrum [7] [8] [9]. In some cases, an oxide zone has been expanded with supergene alteration processes with iron oxide minerals, which is located above the porphyry system. Iron oxides are one of the most important mineral groups that have changed hydrothermally and are accumulated and are particularly converted to altered (yellow or red) stones which are called the Gossan [10]. Hydrothermal alteration minerals with detectable absorption spectral properties, especially at infrared wavelengths near infrared wavelengths, can be used in the early stages to identify porphyry copper deposits as a guide.

In order to prepare a map of alterations and find points with $\mathrm{Cu}$ mineral potential, the area of Orumieh-Dokhtar in the west of Ardestan city is selected. The study area is located in the quadrangle of 1:100,000 Ardestan geological map and between $52^{\circ} 1^{\prime}$ and $52^{\circ} 18^{\prime}$ Eastern latitude and northern latitude $33^{\circ} 17^{\prime}$ to $33^{\circ} 27^{\prime}$ (Figure 1), in the vicinity of the strike-slip Qom-Zefreh fault. Preliminary library studies show that this region has a high $\mathrm{Cu}$ mineral potential in relation to alteration. The rock masses in the study area are located in west of Ardestan (extracted from the geological map of Ardestan 1:100,000) and are mainly as follows: andesite, andesitic basalt, tuff breccia, ignimbrite with some shale and pyro-clastic stone (this rock mass occupies a large part of the studied area), dacite, rhyodacite and locally rhyolitic tuff, gray to light graytuff breccia and ignimbrite. Other lithologies in this area contain Porphyritie andesite, alteration zones, 


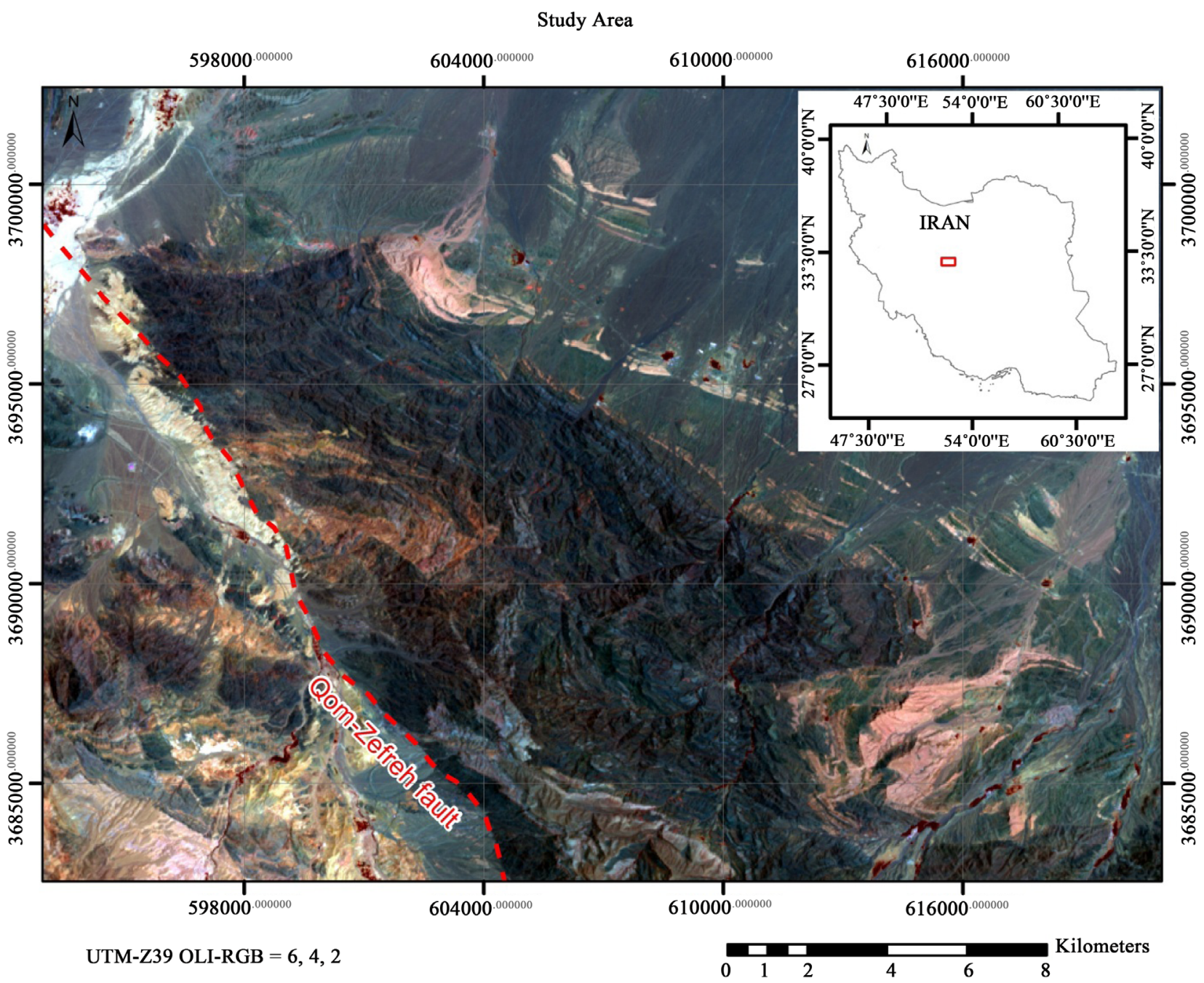

Figure 1. Location of study area in the Qom-Zefreh fault zone.

sandstone, nummulitic limestone, siltstone, marl, andesitic lava, granite and grano- diorites (in small quantities), most of which are related to the period Eocene and, to a lesser extent, Cretaceous, Eocene-Oligocene, Oligocene-Miocene and Miocene.

\section{Materials and Methods}

Considering the proper spectral resolution of the ASTER images, especially in the short-wave Infrared spectral, and the suitability of this spectral range for the identification of alteration minerals and the separation of hydrothermal alteration zones, we can use these data to draw up a map of alterations. Landsat- 8 satellite images can also be used due to an acceptable spectral resolution for detecting locations of iron oxide minerals, Gossan Zones and hydroxyl-containing minerals (Figure 2). Also Landsat-8 satellite images are also be used to identify the lineament, with the appropriate ASTER resolution (16-bit). In this study, the L1T ASTER images March 11, 2008 and Landsat-8 images, July 26, 2014 are 


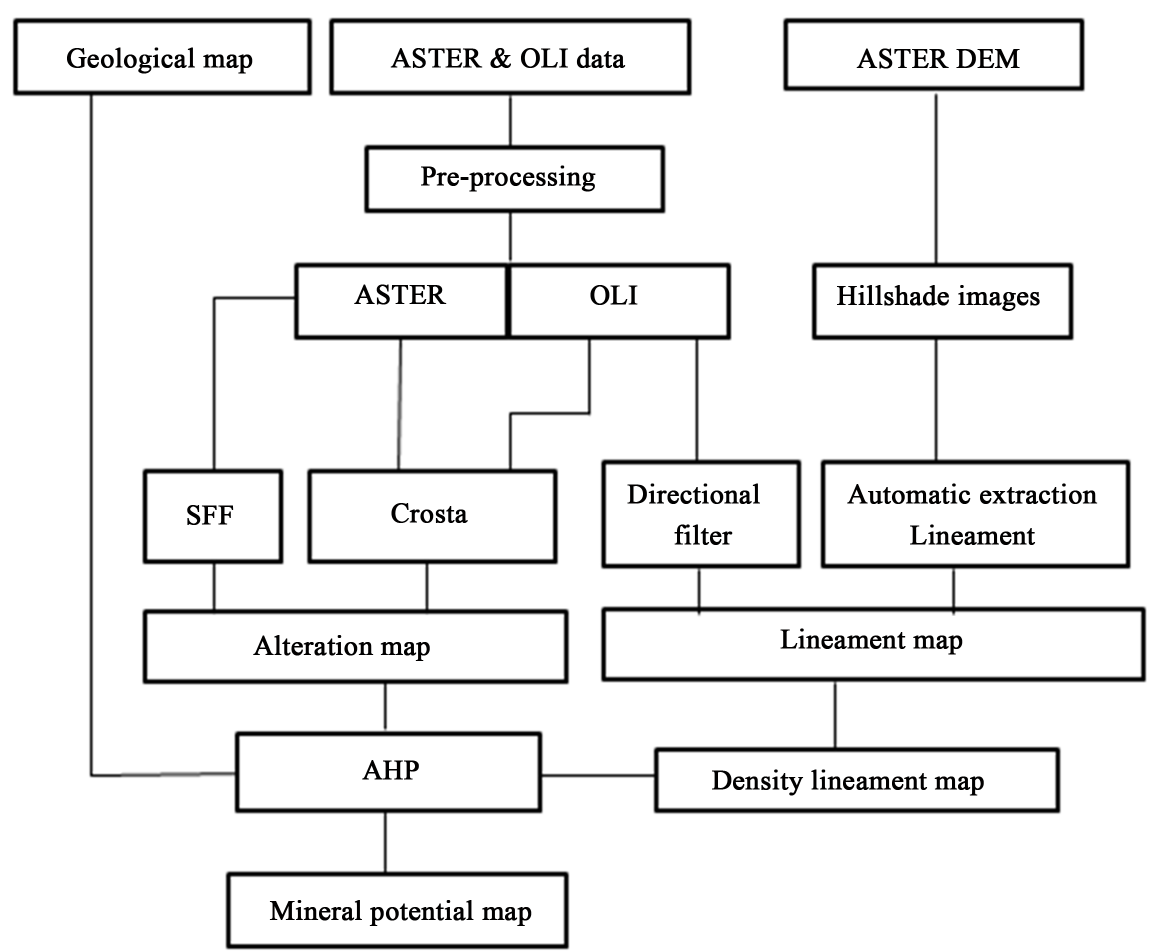

Figure 2. ASTER and OLI processing steps and mapping techniques flowchart.

used, both of which are covered with clouds less than $10 \%$ and the given DEM images in 2011 is used. The geological map of Ardestan that prepared with 1:100,000 scale under the supervision of the Geological Survey of Iran by Emami et al. in 2000, is used.

\subsection{Alteration Zone Detection}

Principal Components Analysis is a technique that converts remote sensing data (which is highly correlated to each other) to more independent, smaller, more compact and more interpretable data [11]. Crosta's method is also a kind of principal components analysis in which bands that are sensitive to target pixels (typically 4 bands) are selected, and then by observing the statistical file obtained by this method and observing the difference between the bands, the best band of the PC is chosen to display the phenomenon (Tables 1-5). The purpose of this method on OLI data is to detect iron oxide and Gossan. For this purpose bands $2,4,5,6$ are used to generate a PC image that features sharp absorption at band 2 and reflection at band 4 for indicating Iron oxide, and bands 2, 3, 4, 6 are used to generate a PC image that features sharp absorption at band 3 and reflection at band 6 for indicating Gossan [12] [13]. The aim of this method on ASTER images is to detect Propylithic, Argillic and Phyllic alterations zones. For this purpose, bands 1, 3, 5, 8bands are used to generate a PC image that features absorption at band 8 and reflection at band 5 for indicating Propylitic alteration zone (Chlorite, Epidote), bands 1, 4, 6, 7 are used to generate a PC image that features absorption at band 6 and reflection at band 4 for indicating Argillic alteration 
Table 1. Correlation between ASTER and PC bands for Epidote representation.

\begin{tabular}{ccccc}
\hline Axis & PC1 & PC2 & PC3 & PC4 \\
\hline ASTER B1 & 0.947296 & 0.298160 & 0.020182 & 0.115426 \\
ASTER B3 & 0.978254 & 0.177071 & -0.036598 & -0.101616 \\
ASTER B5 & 0.973816 & -0.203029 & -0.094829 & 0.038324 \\
ASTER B8 & 0.983543 & -0.146489 & 0.104930 & -0.013176 \\
\hline
\end{tabular}

Table 2. Correlation between ASTER and PC bands for Kaolinite representation.

\begin{tabular}{ccccc}
\hline Axis & PC1 & PC2 & PC3 & PC4 \\
\hline ASTER B1 & 0.903518 & 0.428100 & -0.018877 & -0.005377 \\
ASTER B4 & 0.991147 & -0.098893 & -0.085405 & 0.023515 \\
ASTER B6 & 0.992776 & -0.072644 & 0.031129 & -0.090272 \\
ASTER B7 & 0.994117 & -0.037719 & 0.078522 & 0.064361 \\
\hline
\end{tabular}

Table 3. Correlation between ASTER and PC bands for Muscovite representation.

\begin{tabular}{ccccc}
\hline Axis & PC1 & PC2 & PC3 & PC4 \\
\hline ASTER B1 & -0.940572 & -0.318448 & -0.117780 & 0.006622 \\
ASTER B3 & -0.974500 & -0.197699 & 0.105922 & -0.006730 \\
ASTER B5 & -0.979850 & 0.186021 & -0.021618 & -0.069449 \\
ASTER B6 & -0.981260 & 0.182265 & -0.004023 & 0.062389
\end{tabular}

Table 4. Correlation between OLI and PC bands for Iron oxide representation.

\begin{tabular}{ccccc}
\hline Axis & PC1 & PC2 & PC3 & PC4 \\
\hline OLI B2 & 0.876551 & 0.463749 & 0.126848 & -0.022447 \\
OLI B4 & 0.988166 & 0.128862 & -0.056984 & 0.060618 \\
OLI B5 & 0.994495 & 0.024391 & -0.092055 & -0.043713 \\
OLI B6 & 0.975530 & -0.212103 & 0.057885 & 0.001860 \\
\hline
\end{tabular}

Table 5. Correlation between OLI and PC bands for Gossan representation.

\begin{tabular}{ccccc}
\hline Axis & PC1 & PC2 & PC3 & PC4 \\
\hline OLI B2 & 0.897818 & 0.426595 & -0.107072 & 0.021803 \\
OLI B3 & 0.979760 & 0.195226 & 0.015888 & -0.041286 \\
OLI B4 & 0.991171 & 0.087835 & 0.097432 & 0.019304 \\
OLI B6 & 0.967158 & -0.252288 & -0.030910 & 0.001082 \\
\hline
\end{tabular}

zone (Kaolinite, Montmorillonite), and 1, 3, 5, 6 bands are used to generate a PC image that features sharp absorption at band 6 and reflection at band 5 for indicating Phyllic alteration (Sericite) [14] [15].

Spectral Feature Fitting (SFF) is a technique that uses peak or peaks of absorption in the entire spectral pixel curve and by comparing it (its location and geometry) with the reference spectrum (mineral spectrum library) it uses mineral or 
the target phenomenon to identify given phenomenon [16] [17]. The SFF method is only performed on ASTER images. This method is performed on the basis of USGS spectrum library to display the index minerals including Epidote, Chlorite, Kaolinite, Montmorillonite, and Muscovite, to identify Propylithic, Argillic and Phyllic alteration zones respectively. The mapping of the alterations obtained in this study is presented in Figure 3.

\subsection{Lineament Mapping}

A directional filter with a kernel size $=3 \times 3$ and angles of $0,45,90,135,180$, 225,270 , and 315 is performed on OLI images. Then, to reduce the dimensions of the data, the PCA conversion on the images obtained from each angle is performed in order to minimize the dimensions of the data and to collect the most information in a band.

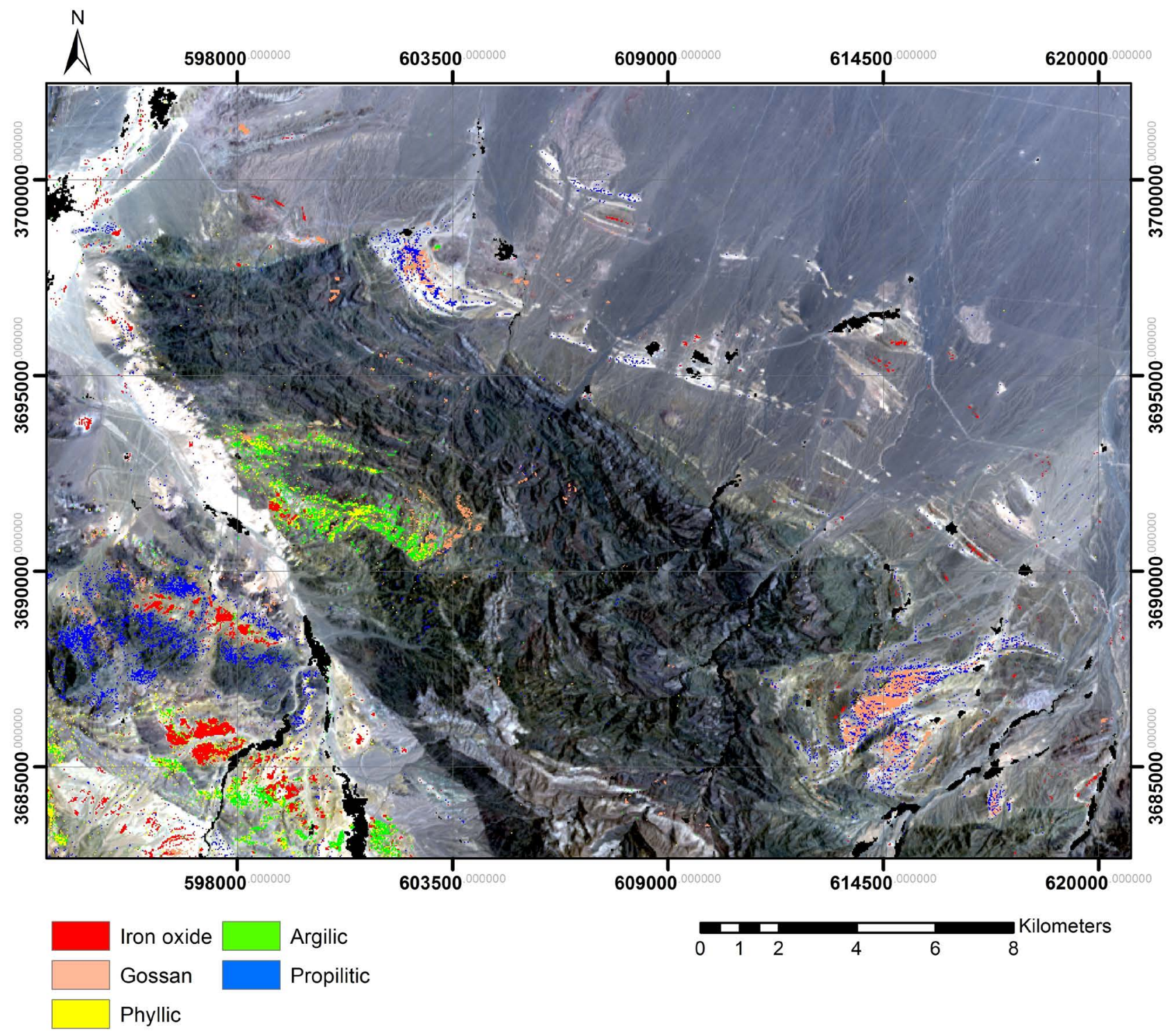

Figure 3. Hydrothermal alteration zones on OLI image, RGB: 432. 
Two groups of hill shade images are also obtained from DEM images with a 45-degree angle and Azimuth's angles of 0, 45, 90, 135 (as the first group) and $180,225,270$, and 315 (as the second group). Then, by the difference between the average of the first group and the average of the second group, an image is obtained. This image is used to extract the lineament and the lineament is extracted well. The map of the lineament and the density of the lineament are shown in (Figure 4).

\section{Results}

As it is shown in the mapping the alterations (Figure 3), two Argillic and Phyllic alteration zones are highly interrelated and the Propylitic zone is present in a small amount around them, which is indicative of Propylitic system in the region. Also, the high density of the lineament interrelating with Argillic and Phyllic alterations that represent a circular structure in this region, increases the probability of mineral potential. By integrating the mapping of the alterations and mapping the density of the lineament with the geological map of the region, a compilation map is created to identify the mineral potential areas. Subsequently, mineral potential areas are determined by implementing multi-criteria decision making, Analytical Hierarchy Process (AHP) method on three criteria: lithology, alteration and lineament density. In decision making AHP method for this study, three main criteria that are directly related to mineralization are considered. Each of the main criteria is effective by several sub-criteria. For example alteration has two sub-criteria: 1) High accumulation (full zonation of alterations) 2) Low accumulation (incomplete zonation of alterations), (Table 6,

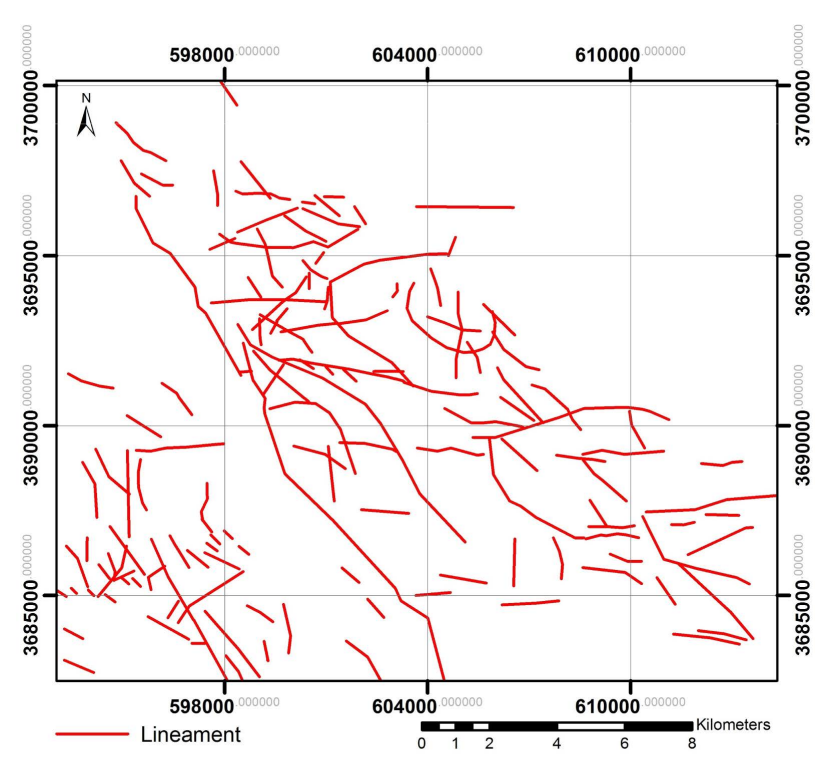

(a)

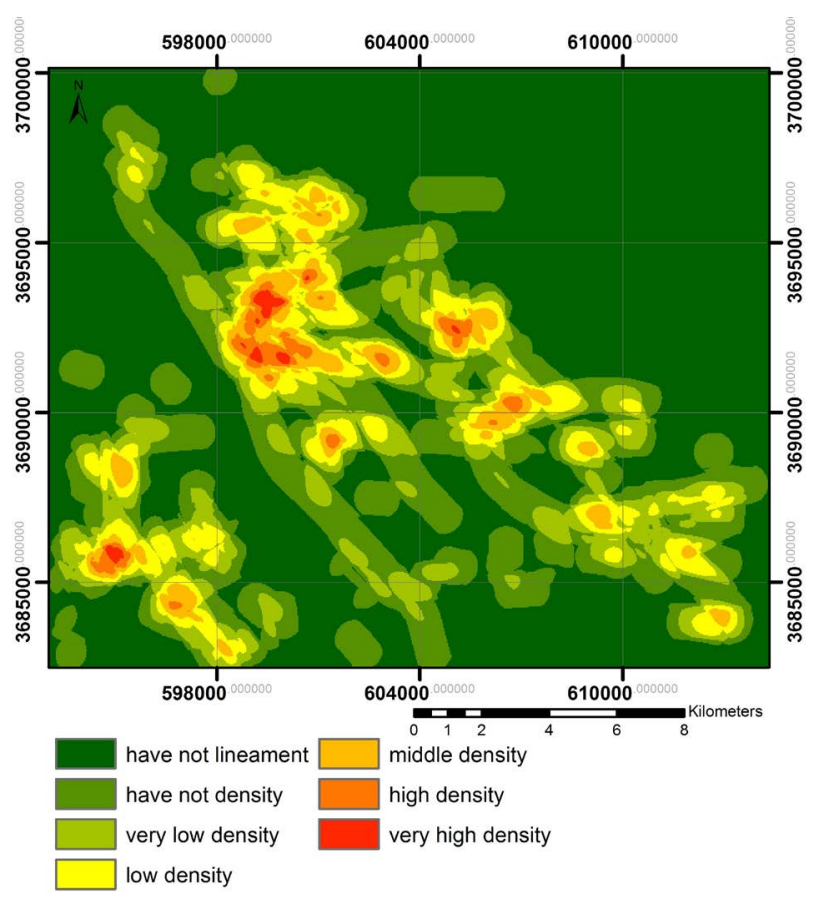

(b)

Figure 4. (a) Lineament map of study area; (b) Lineament density map. 
Table 6. The weight value for criterion and sub-criterion.

\begin{tabular}{|c|c|c|}
\hline Weight & Criterion & AHP value \\
\hline 0.625 & Lithology & \\
\hline 0.238 & Alteration & \\
\hline 0.136 & Lineament & \\
\hline Weight & Sub-criterion: Lithology types & AHP value \\
\hline 0.226 & $\begin{array}{l}\text { Rhyodacite, Dacite, Rhyolitic tuff-Andesitic basalt, } \\
\text { Andesite, Acidic volcanics (rhyolite-dacite)-Porphyritie } \\
\text { andesite and Dacitic andesite }\end{array}$ & 0.14125 \\
\hline 0.194 & Hydrothermally altered zone & 0.12125 \\
\hline 0.161 & Altered andesitic lava-Rhyolite-Rhyodacite tuff and ignimbrite & 0.100625 \\
\hline 0.129 & Granite, Granodiorite & 0.080625 \\
\hline 0.097 & $\begin{array}{l}\text { Alternation limestone and Andesitic lava-Young and } \\
\text { Low level traces Old and High level } \\
\text { traces-Recent alluvium-Old and Young fans }\end{array}$ & 0.060625 \\
\hline Weight & Sub-criterion: Lineament density & AHP value \\
\hline 0.263 & Very high density & 0.062594 \\
\hline 0.204 & High density & 0.048552 \\
\hline 0.178 & Middle density & 0.042364 \\
\hline 0.142 & Low density & 0.033796 \\
\hline 0.107 & Very low density & 0.025466 \\
\hline 0.071 & No density & 0.016898 \\
\hline Weight & Sub-criterion: Alteration & AHP value \\
\hline 0.528 & High accumulation & 0.071808 \\
\hline 0.077 & Low accumulation & 0.010472 \\
\hline
\end{tabular}

Table 7 and Figure 5). In field surveys, the points identified by spectral processing are sampled (Figure 6 and Figure 7), and from these samples, thin sections are prepared. In the study of thin sections, Feldspar (with alteration effects) can be seen in the background of clay (Figure 8(a)), in these sections, Sericite and Epidote also are well visible (Figures 8(b)-(d)). Therefore, the study of thin sections confirms the accuracy of the alteration spectral processing performed in this study.

\section{Conclusion}

- Table 7 shows the highest AHP values for different areas. These values are the sum of the multiplication of the criteria with sub-criteria of each area. Areas with the highest AHP values show high potential for $\mathrm{Cu}$ mineralization. 

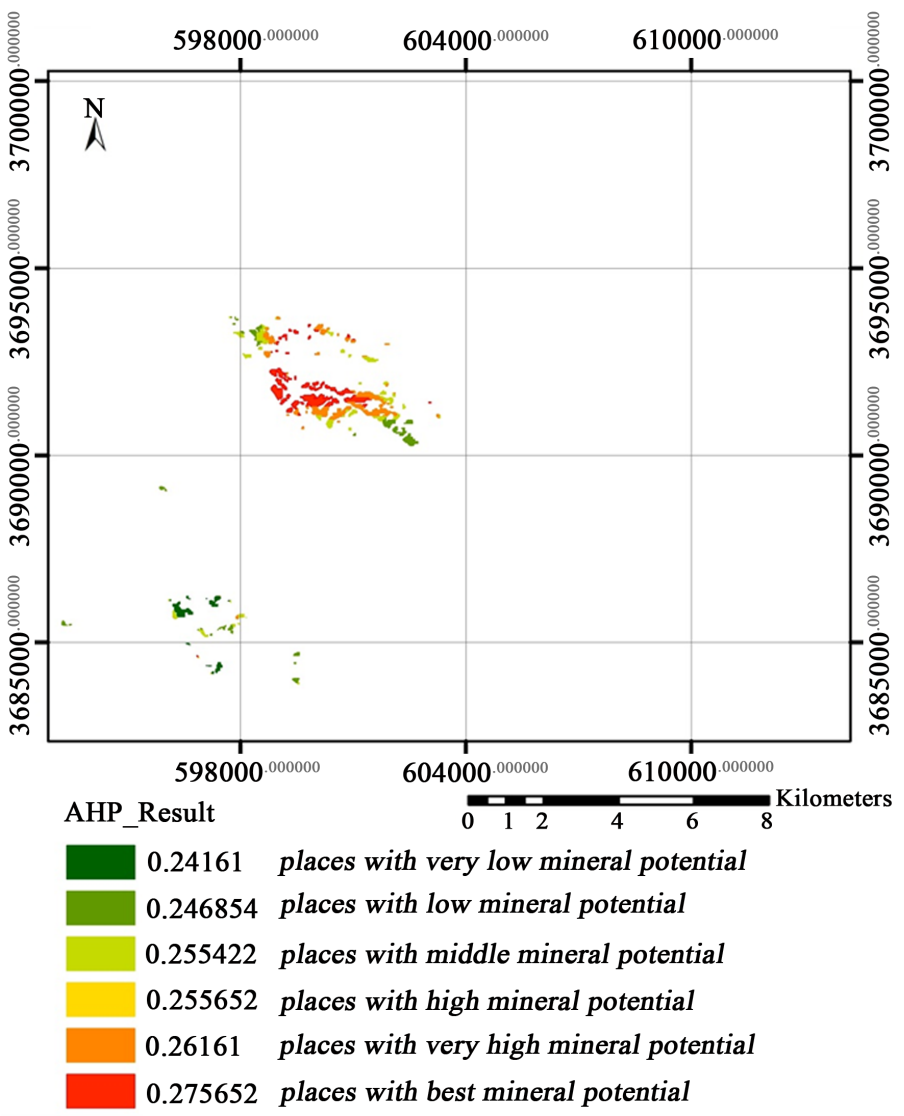

Figure 5. Mineral promising areas derived from multi-criteria decision making by AHP method with lithology, lineament density and alteration criteria; red ranges represent the highest potential.

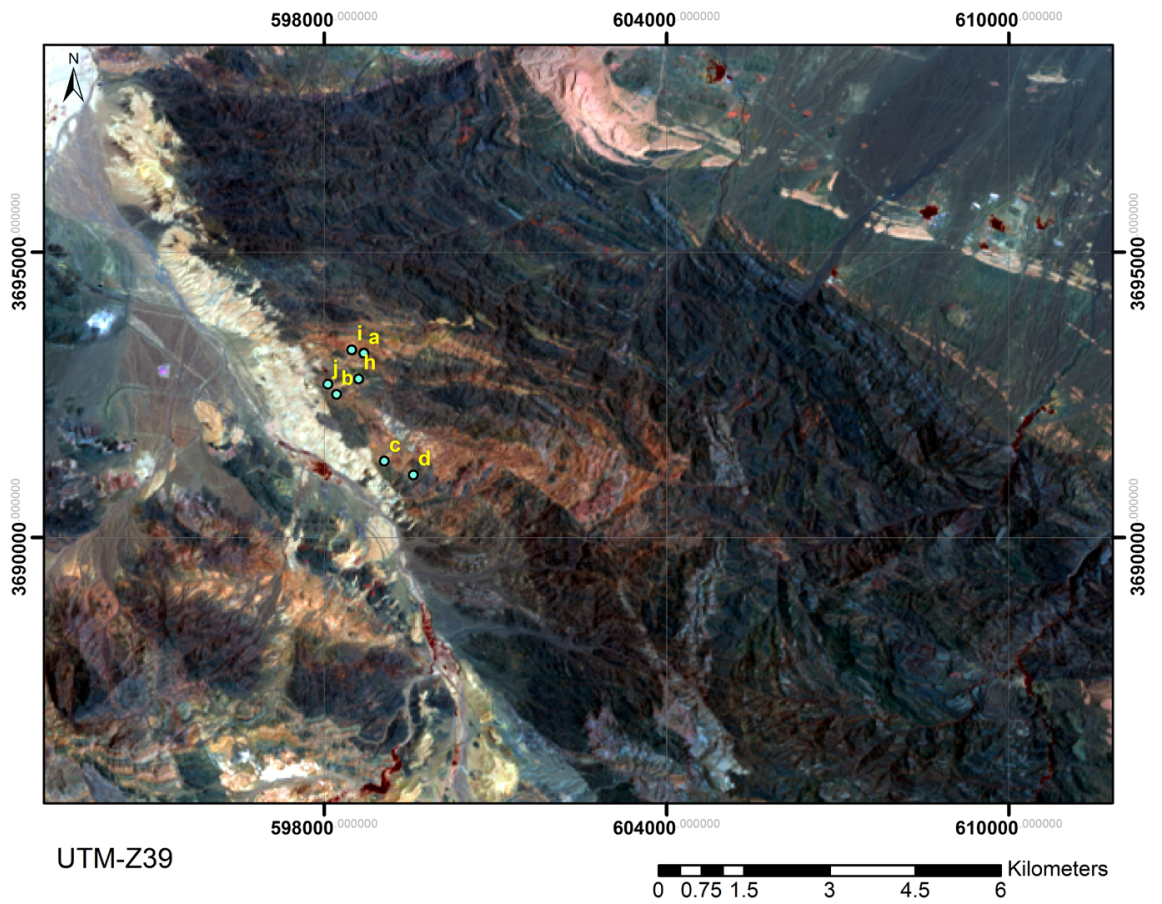

Figure 6. Map of sampling points in the area. 


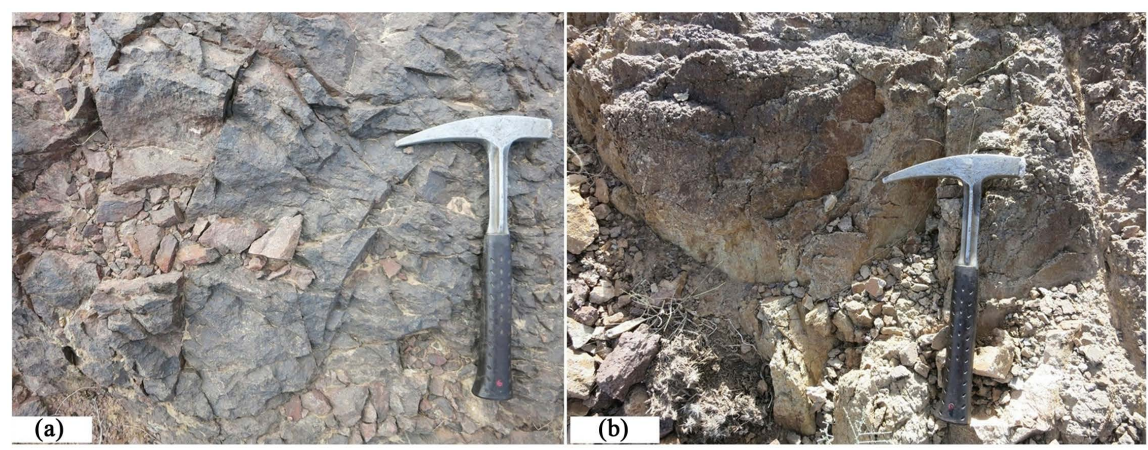

Figure 7. Images of rock units from two sampling points: (a) point C (altered volcanic rock), (b) point $\mathrm{D}$ (the feldspar, altered to sericite).
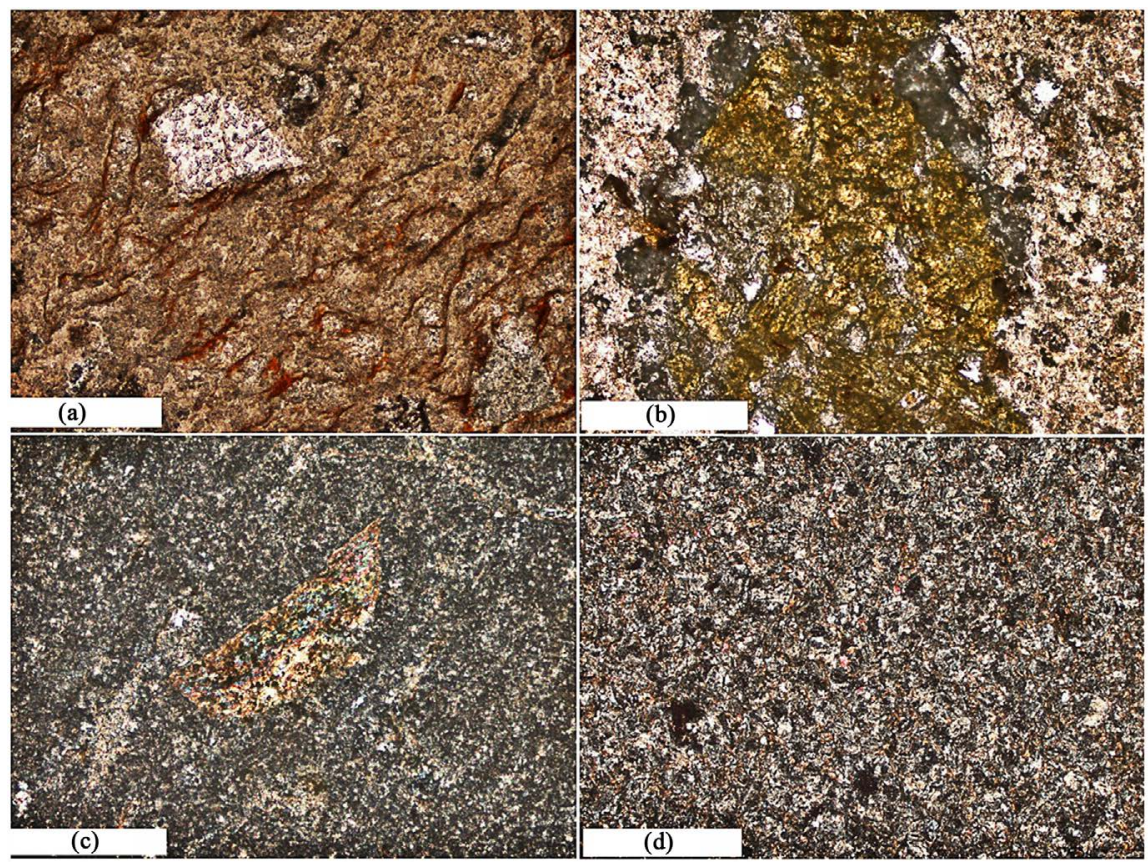

Figure 8. Fourth in-section images of the study: (a) XPL 100×; Feldspar with alteration effects in the context of clay related to the sampling point C; (b) XPL 100×; Epidote in altered context from the sampling point A; (c) PPL 100x; Plagioclase altered to sericite in the fine grains context related to the sampling point D; (d) PPL 40×; The fine grain texture is altered, sampling point $\mathrm{H}$.

Table 7. Highest AHP values for different areas.

\begin{tabular}{lllllll}
\hline AHP-value & 0.275652 & 0.26161 & 0.255652 & 0.255422 & 0.246854 & 0.24161 \\
\hline
\end{tabular}

- The use of ASTER images due to the proper spectral resolution, especially in the spectral range of SWIR, for the presentation of clay minerals and alternation zones and OLI data, also has spectral resolution suitable in the VNIR spectral range that is very useful for the appearance of iron oxide minerals and Gossan zone. Therefore, it is better to use both types of data to explore mineral resources (especially metal deposits).

- In order to visualize the lineament, the hill shade images and directional fil- 
tering are used and at the end of the lineaments that are common in both methods, are used to produce a map of the lineament. In this study, these two methods are very useful due to viewing the image from different angles.

- In this study, due to the identification of the circular structure in the region and the concentration of points with mineral potential on it, the importance of these types of structures in identifying areas with mineral potential areas was emphasized.

\section{References}

[1] Asadi, H., Sansoleiman, A. and Pireh, L. (2012) Evaluation of Mineralization Potential in 1:100000 Geological Map of Ardestan Using Fuzzy Logic Method. 1st Iranian Mining Technologies Conference-IMT2012, 5-7 September 2012, University of Yazd, 13-21.

[2] Heidrick, T.L. and Titley, S.R. (1982) Fracture and Dike Patterns in Laramide Plutons and Their Structural and Tectonic Implications, American Southwest. In: Titley, S.R., Ed., Advances in Geology of the Porphyry Copper Deposits of the American Southwest, University of Arizona Press, Tucson, 73-91.

[3] Misra, K.C. (2000) Understanding Mineral Deposits. Kluwer Academic Pub., 20 p. https://doi.org/10.1007/978-94-011-3925-0

[4] Khosroshahizadeh, Sh., Pourkermani, M., Almasian, M., Arian, M. and Khakzad, A. (2016) Lineament Patterns and Mineralization Related to Alteration Zone by Using ASAR-ASTER Imagery in Hize Jan-Sharaf Abad Au-Ag Epithermal Mineralized Zone (East Azarbaijan-NW Iran). Open Journal of Geology, 6, 232-250. https://doi.org/10.4236/ojg.2016.64021

[5] Asadi, H. and Hale, M. (1999) Integrated Analysis of Aeromagnetic, Landsat TM and Mineral Occurrence Data for Epithermal Gold Exploration in Northwest Iran. Proceedings of the Thirteenth International Conference on Applied Geologic Remote Sensing, Vancouver, British Columbia, Canada, 1-3 March, 8 p.

[6] Legge, C.A. (1997) The Application of Multitemporal Remote Sensing Data and Aerial Photographs in the Management and Monitoring of Coastal Areas and Parks in Kenya. The Fourth International Conference on Remote Sensing and Costal Environment, Orlando, FL, USA. Heinrich Boll Foundation, 1997.

[7] Sabins, F.F. (1999) Remote Sensing for Mineral Exploration. Ore Geology Reviews, 14, 157-183. https://doi.org/10.1016/S0169-1368(99)00007-4

[8] Abdelsalam, M. and Stern, R. (2000) Mapping Gossans in Arid Regions with Landsat TM and SIR-C Images, the Beddaho Alteration Zone in Northern Eritrea. Journal of African Earth Sciences, 30, 903-916. https://doi.org/10.1016/S0899-5362(00)00059-2

[9] Xu, Y., Lin, Q.Z., Yun, S. and Lu, W. (2004) Extraction Mechanism of Alteration Zones using ASTER Imagery. Proceedings of IEEE International Geoscience and Remote Sensing Symposium, 20-24 September 2004, 4174-4175.

[10] Beiranvand Pour, A. and Hashim, M. (2011) Application of Advanced Spaceborne Thermal Emission and Reflection Radiometer (Aster) Data in Geological Mapping. International Journal of Physical Sciences, 6, 7657-7668.

[11] Jensen, J.R. (2004) Introductory Digital Image Processing. 296-301.

[12] Beiranvand Pour, A. and Hashim, M. (2015) Regional Hydrothermal Alteration Mapping Using Landsat-8 Data, Geoscience and Digital Earth Centre (Geo-DEC). 
Research Institute for Sustainability and Environment, Universiti Teknologi Malaysia (UTM). https://www.researchgate.net/publication/281434756

[13] Madani, A. (2013) Assessment and Evaluation of Band Ratios, Brovey and HSV Techniques for Lithologic Discrimination and Mapping Using Landsat $\mathrm{ETM}^{+}$and SPOT-5 Data. International Journal of Geosciences, 5, 5-11.

http://www.scirp.org/journal/ijg https://doi.org/10.4236/ijg.2014.51002

[14] Yajima, T. (2014) Aster Data Analysis Applied to Mineral Resource Exploration and Geological Mapping, Case Study Meiduk Area Located in the Kerman Province of Iran. A Dissertation for the Degree of Doctor of Sciences, Graduate School of Environmental Studies, Nagoya University, 20 p.

[15] Yetkin, E. (2003) Alteration Mapping by Remote Sensing, Case Study HASANDAĞ-MELENDİZ Volcanic Complex in Turkey. A Thesis for the Degree of Master of Science, Middle East Technical University of Turkey, 20 p.

[16] Daryani, N., Arian, M. and Rashidnezhad Omran, N. (2015) Tectonics and Mineralization of Copper in the Ardestan-Kahang Area, Central Iran by Remote Sensing. Open Journal of Geology, 5, 188-196. https://doi.org/10.4236/ojg.2015.54017

[17] Clark, R.N., Gallagher, A.J. and Swayze, G.A. (1990) Material Absorption Band Depth Mapping of Imaging Spectrometer Data Using a Complete Band Shape Least-Squares Fit with Library Reference Spectra. JPL Publication, 90-54, 176-186.

Submit or recommend next manuscript to SCIRP and we will provide best service for you:

Accepting pre-submission inquiries through Email, Facebook, LinkedIn, Twitter, etc. A wide selection of journals (inclusive of 9 subjects, more than 200 journals)

Providing 24-hour high-quality service

User-friendly online submission system

Fair and swift peer-review system

Efficient typesetting and proofreading procedure

Display of the result of downloads and visits, as well as the number of cited articles

Maximum dissemination of your research work

Submit your manuscript at: http://papersubmission.scirp.org/

Or contact ojg@scirp.org 